\title{
FUNDAMENTOS Y ACCIONES PARA LA APLICACIÓN DEL LEVANTAMIENTO DEL VELO EN CHILE
}

\author{
FOUNDATIONS AND ACTIONS FOR THE APPLICATION OF THE VEIL \\ PIERCING IN CHILE
}

Jorge Ugarte ViaL*

RESUMEN: El presente artículo tiene por objeto analizar los fundamentos y acciones para aplicar el levantamiento del velo en Chile, tanto en materia civil como comercial, a la luz de algunos fallos dictados en los últimos años por los tribunales superiores de justicia chilenos. En la parte inicial se define el levantamiento del velo como un procedimiento judicial de carácter excepcional, en virtud del cual cabe prescindir en ciertos casos de la separación personal y patrimonial entre una sociedad de cuya estructura jurídica se ha abusado, por una parte, y uno o más de sus socios, administradores o sociedades relacionadas, por otra, para evitar así que un fraude o abuso produzca efectos. A continuación, se revisan los supuestos de hecho ante los cuales cabe aplicar el levantamiento del velo y se examinan las reglas de derecho común que permiten fundar dicha aplicación en Chile, como aquellas que prohíben el fraude a la ley, el fraude a los derechos de terceros, el abuso del derecho, la simulación ilícita, la causa ilícita y los actos de mala fe. Posteriormente, se analizan la acción y excepción de inoponibilidad por abuso de la personalidad jurídica como medios idóneos para obtener el levantamiento del velo en Chile. Para terminar, se proponen algunas conclusiones.

Palabras clave: Abuso del derecho, abuso de la personalidad jurídica, fraude, inoponibilidad, personalidad jurídica, sociedades.

ABSTRACT: The purpose of this article is to analyze the foundations and actions for applying the veil piercing in Chile, both in the civil and commercial fields, in the light of certain rulings issued by the Chilean high courts during the last years. In the initial part, the veil piercing is defined as a judicial proceeding of exceptional character, by virtue of which it is possible in some cases to disregard the personal and patrimonial separation between one company whose legal structure has been abused of, on the one hand, and one or more of its partners, administrators or related companies, on the other hand, to prevent a fraud or abuse from producing effects. Following, the factual circumstances under which it is possible to apply the veil piercing are reviewed, and the common rules of law that make it possible to found such application in Chile are examined, including those forbidding fraud against law, fraud against the rights of third parties, abuse of right, illicit simulation, illicit cause and the acts in bad faith. Afterwards, the action and defense of unenforceability against third parties due to abuse of the legal entity are analyzed as suitable means to obtain the veil piercing in Chile. Finally, some conclusions are proposed.

Key words: Abuse of right, abuse of the legal entity, corporations, fraud, legal entity, unenforceability.

Profesor de Derecho Comercial, Pontificia Universidad Católica de Chile. 


\section{INTRODUCCIÓN}

La personalidad jurídica de las sociedades constituye un elemento fundamental del derecho occidental, y como tal ha contribuido substancialmente al desarrollo de la economía moderna. Sin embargo, no es difícil constatar que en Chile, al igual que en otros países, se dan distintas situaciones de abuso de la personalidad jurídica: así ocurre, por ejemplo, cuando se utiliza una sociedad o grupo de sociedades no como un mecanismo idóneo para el desarrollo de empresas, sino como un medio para burlar la ley o defraudar los derechos de terceros ${ }^{1}$.

Supóngase por ejemplo que una persona aporta a una sociedad ciertos bienes personales para evadir el cumplimiento de sus obligaciones ante un acreedor e impedir que este pueda ejercer sus derechos sobre los bienes transferidos, y que la acción pauliana se encuentra prescrita. Considerado aisladamente, este aporte en sociedad es un acto jurídico inatacable, pues las partes involucradas -el socio y la sociedad- han tenido una voluntad real y sin vicios de realizar efectivamente la transferencia y ninguna de ellas ha sufrido perjuicio; en realidad, la verdadera víctima del fraude es el acreedor personal del socio, que en rigor es un tercero ajeno al aporte en sociedad como acto jurídico y, por consiguiente, no tiene acción de nulidad relativa por dolo. Según puede observarse, el socio ha realizado un acto formalmente lícito, como es un aporte en sociedad; pero lo que en realidad ha hecho es aprovecharse de tal acto para instrumentalizar la personalidad jurídica y el patrimonio separado de la sociedad y obtener así un fin ilícito, consistente en eludir la norma en virtud de la cual debe cumplir sus obligaciones ante un acreedor personal.

Para combatir este y otros abusos análogos que reflejan una utilización fraudulenta de sociedades o grupos de sociedades, diversos ordenamientos de derecho comparado han venido contemplando desde hace décadas un procedimiento judicial comúnmente llamado "levantamiento del velo" 2 , en virtud del cual se permite excepcionalmente al juez prescindir en un caso concreto de la personalidad jurídica y patrimonio separado de una sociedad, en términos tales que los derechos u obligaciones que se ha tratado de eludir mediante la comisión de un acto fraudulento se atribuyan directamente a quien ha cometido o permitido tal abuso, sea que se trate de un socio, de un administrador con poderes para controlar de hecho a la compañía o de una sociedad relacionada. En un fallo notable del año 2007 en que aplicó la técnica del levantamiento del velo, la Corte de Apelaciones de Punta Arenas aseveró que "es lícito a los tribunales en ciertas ocasiones ignorar o prescindir de la forma externa de la persona ju-

\footnotetext{
1 En el pasado, esta clase de abusos se daba básicamente mediante la utilización fraudulenta de sociedades, particularmente de aquellas en que la responsabilidad de los socios se encuentra limitada al monto de su aporte, pero hoy en día es posible también perpetrarlos mediante la instrumentalización de empresas individuales de responsabilidad limitada, cuyo establecimiento fuera autorizado por la Ley 19.857 de 2003. Por lo anterior, lo que se diga en este artículo respecto del abuso de la personalidad jurídica societaria debe entenderse también como aplicable al abuso de la personalidad jurídica de las empresas individuales de responsabilidad limitada, salvo que de la naturaleza misma de estas últimas se desprenda lo contrario.

2 Este procedimiento ha recibido una variedad de nombres, entre los cuales, además de "levantamiento del velo societario" (lifting of the corporate veil), se encuentran "perforación del velo societario" (piercing of the corporate veil), "allanamiento", "inoponibilidad", "desestimación" y "prescindencia de la personalidad jurídica" (disregard of the legal entity).
} 
rídica, para con posterioridad penetrar en su interior a fin de develar los intereses subyacentes que se esconden tras ella y alcanzar a las personas y bienes que se amparan bajo el velo de la personalidad, con el objeto de poner fin a fraudes y abusos mediante la aplicación directa de las normas jurídicas a los individuos que pretendían eludirlas y la declaración de inoponibilidad de la persona jurídica respecto de los terceros que resulten perjudicados"3.

Sin perjuicio de lo anterior, conviene tener presente que la técnica judicial del levantamiento del velo debe considerarse como un recurso excepcional, ya que un abuso del mismo podría menoscabar la protección que se debe a las sociedades, a su personalidad jurídica y a su patrimonio separado, los cuales, como se dijo más arriba, resultan esenciales para el ordenamiento social, tanto desde un punto de vista jurídico como económico.

\section{SUPUESTOS NECESARIOS PARA QUE SE CONFIGURE UN ABUSO DE LA PERSONALIDAD JURÍDICA Y PUEDA APLICARSE EL LEVANTAMIENTO DEL VELO}

A la luz del derecho comparado y de los fallos de los tribunales chilenos a que se aludirá más adelante, puede decirse que el abuso de la forma societaria y la consiguiente aplicación de la técnica judicial del levantamiento del velo tienen lugar ante la presencia de dos supuestos copulativos: primero, la identidad personal o patrimonial entre una sociedad y uno o más de sus socios, administradores o sociedades relacionadas; y segundo, la instrumentalización abusiva de tal sociedad para la consecución de un fraude a la ley o a los derechos de terceros. A continuación se analizará cada uno de ellos por separado.

\section{IDENTIDAD PERSONAL O PATRIMONIAL.}

El primer supuesto necesario para la aplicación del levantamiento del velo consiste en la unidad de hecho entre dos personas o patrimonios que, si bien desde el punto de vista de las formalidades legales exteriores podrían considerarse distintos, en la práctica carecen de aquella autonomía económica y funcional necesaria para que opere entre ellas una separación real que el derecho deba necesariamente reconocer. Esta identidad entre personas o patrimonios supuestamente independientes puede concretarse de diversas maneras: en algunos casos se trata de una "identidad vertical" entre la sociedad y uno o más de sus socios, o entre la sociedad y uno o más de sus administradores cuyos poderes son tan amplios que les permiten manejar la compañía de manera prácticamente unilateral ${ }^{4}$; en otras oportunidades, en cambio, se trata de una "identidad horizontal" entre dos o más sociedades sujetas a la dirección

3 Véase “Catrilef Hernández, Salomón y otros con Pesca Cisne S.A.” (Corte de Apelaciones de Punta Arenas, Rol $\mathrm{N}^{\circ}$ 230-2007). Excelente es la definición que de este procedimiento da el inciso tercero del artículo 54 de la Ley de Sociedades Comerciales argentina, incorporado en 1983: "Inoponibilidad de la Persona Jurídica. La actuación de la sociedad que encubra la consecución de fines extrasocietarios, o constituya un mero recurso para violar la ley, el orden público o la buena fe o para frustrar derechos de terceros, se imputará directamente a los socios o a los controlantes que la hicieron posible, quienes responderán solidaria e ilimitadamente por los perjuicios causados".

4 Véase, por ejemplo, "Proinvest Promotora de Inversiones S.A. con Trends Ingeniería S.A. y Datun Chile S.A.” (Corte de Apelaciones de Santiago, Rol No 6273-2010), en que el tribunal aplicó la doctrina del levantamiento del velo considerando entre otras razones la identidad entre las sociedades Trends Ingeniería S.A. e Inversiones San Javier S.A. y el representante legal de ambas, don Rodrigo Alamiro Silva Millán. 
de un mismo controlador ${ }^{5}$. En uno u otro caso, la identidad personal o patrimonial suele reflejarse en una variedad de signos exteriores, como la mezcla de activos personales y sociales, la inobservancia de las formalidades societarias, la ausencia de oficinas separadas, la presencia de idénticos administradores en las distintas compañías de un mismo grupo empresarial, o la abstención de explotar el giro social u otras actividades económicas ${ }^{6}$.

En relación con lo anterior, es posible advertir que la jurisprudencia chilena que ha sancionado el abuso de la personalidad jurídica y aplicado el levantamiento del velo ha puesto especial empeño en tener por acreditada la unidad o confusión patrimonial o personal entre una compañía y uno o más de sus socios o representantes legales, o entre varias compañías pertenecientes a un mismo grupo empresarial, pues una identidad de este tipo puede en algunos casos reflejar una distorsión de los fines para cuyo cumplimiento la ley reconoce personalidad jurídica y patrimonio separado a las sociedades, como son el desarrollo de empresas y la seguridad de los acreedores sociales y personales de los socios ${ }^{7}$. Como se verá más adelante, este primer supuesto es un elemento fundamental para distinguir la naturaleza de la acción en virtud de la cual se solicita el levantamiento del velo, por una parte, y la acción pauliana, por otra.

\section{Conducta abusiva o Fraudulenta.}

Con todo, la identidad personal o patrimonial entre uno o más socios o administradores y una sociedad determinada, o entre varias sociedades pertenecientes a un mismo grupo empresarial, no constituye de por sí un abuso de la personalidad jurídica. Por el contrario, para que exista tal abuso y el juez pueda entonces prescindir en un caso concreto de la forma societaria, debe presentarse adicionalmente un segundo supuesto, consistente en la instrumentalización de la estructura jurídica de una sociedad o grupo de sociedades para perpetrar un fraude a la ley o a los derechos de un tercero: de ahí justamente deriva la ilicitud de tal conducta. Así se desprende de los fallos de los tribunales superiores de justicia chilenos que han aplicado el levantamiento del velo, como aquel de la Corte Suprema del año 2008, en que el máximo tri-

\footnotetext{
5 Véase "Catrilef Hernández, Salomón y otros con Pesca Cisne S.A." (Corte de Apelaciones de Punta Arenas, Rol N²30-2007).

6 En el derecho comparado se ha considerado que las situaciones que generalmente implican o reflejan un abuso de la personalidad jurídica pueden incluir, entre otras, sociedades constituidas o utilizadas para evadir obligaciones ante terceros, aportes sociales efectuados bajo la forma de un crédito otorgado por los socios, mayoría unilateral en la propiedad del capital por parte de un solo socio, sociedades que hacen creer a terceros que otra compañía cuenta con su apoyo económico, dominación económica por parte de otra persona o compañía, utilización de la sociedad por un director para fines personales, continuación en la explotación de una sociedad a sabiendas de su insolvencia, y significativa confusión entre los activos sociales y personales de los socios (Dobson, 1986, 840).

7 Sobre la identidad personal o patrimonial como presupuesto de la aplicación del levantamiento del velo, véase "Catrilef Hernández, Salomón y otros con Pesca Cisne S.A." (Corte de Apelaciones de Punta Arenas, Rol No 230-2007), "Consorcio Allianz de Seguros Generales S.A. con Sociedad Naviera Ultragas Ltda. y Ultramar Agencia Marítima Ltda." (Corte Suprema, Rol N 1527-2008), "Proinvest Promotora de Inversiones S.A. con Trends Ingeniería S.A. y Datun Chile S.A.” (Corte de Apelaciones de Santiago, Rol N 6273-2010), "Scharfstein S.A. con Browne Keeling y Cía. Ltda. y Emparanza Paiva, Margarita Juliana" (Corte de Apelaciones de Santiago, Rol N 771-2010). En todos estos casos, el tribunal respectivo hizo un detallado análisis de las circunstancias que demostraban la unidad personal o patrimonial de una sociedad con uno o más de sus socios, representantes o compañías relacionadas.
} 
bunal sostuvo que el levantamiento del velo permite dar solución "a situaciones de manifiesto abuso de la personalidad jurídica, en que sociedades aparentemente autónomas e independientes jurídica y económicamente, responden a una misma unidad económica y de organización, porque existe tal control de la una sobre la o las otras, que esta o estas últimas no son sino un alter ego de la dominante, utilizada para obtener un resultado antijurídico"8.

Es decir, no basta la unidad económica y funcional para aplicar la técnica del levantamiento del velo, sino que debe darse adicionalmente una utilización abusiva de la forma societaria para la consecución de un resultado antijurídico, en particular para la producción de un fraude a la ley o a los derechos de un tercero. Por lo demás, así se ha establecido en países que cuentan con una mayor experiencia en la materia, como Estados Unidos, donde las distintas doctrinas que las cortes tienen presentes para aplicar el levantamiento del velo (como el instrumentality test, el alter ego o la enterprise liability) implican no solo la identidad personal o patrimonial, sino también la utilización abusiva de la sociedad o grupo de sociedades para la comisión de un fraude o un delito, o para violar de cualquier manera los derechos de un tercero ${ }^{9}$. Lo mismo ocurre en España, donde la jurisprudencia no considera aplicable la doctrina del levantamiento del velo si no se da una actuación fraudulenta ${ }^{10}$.

Ahora bien, aunque el ordenamiento jurídico chileno no contempla un tratamiento expreso y sistemático del abuso de la personalidad jurídica, es posible determinar su ilicitud y sancionarlo acudiendo a las reglas del derecho común, incluyendo aquellas que castigan el fraude a la ley, el fraude a los derechos de terceros, el abuso del derecho, la conducta contraria a los actos propios, la simulación ilícita, la causa ilícita y los actos de mala fe, entre otras. Los siguientes párrafos tienen por objeto analizar de qué modo puede determinarse la existencia de un abuso de la personalidad jurídica y aplicarse el levantamiento del velo conforme al ordenamiento chileno actualmente vigente en materia civil y comercial, con especial referencia a algunos fallos de los tribunales superiores de justicia chilenos que en el último tiempo han acogido esta doctrina de modo manifiesto.

\section{EL ABUSO DE LA PERSONALIDAD JURÍDICA MEDIANTE LA COMISIÓN DE UN FRAUDE}

El profesor Ramón Domínguez Águila observa que, en un sentido amplio o genérico, el fraude, al igual que el dolo, puede definirse como una conducta contraria a la buena fe;

\footnotetext{
8 "Consorcio Allianz de Seguros Generales S.A. con Sociedad Naviera Ultragas Ltda. y Ultramar Agencia Marítima Ltda." (Corte Suprema, Rol N 1527-2008).

9 Respecto del instrumentality test, véase O'Kelly y Thompson (2006) p. 547; respecto de la doctrina del alter ego, véase BAINBRIDGE (2002) pp. 128-130; y respecto de la doctrina de la enterprise liability, véase BAINBRIDGE (2002) pp. 168-171. De modo general cabe señalar que, aunque en Estados Unidos la prescindencia de la personalidad jurídica y de la responsabilidad limitada de los socios ha sido acogida por las cortes mediante la elaboración de distintas doctrinas, todas ellas coinciden en exigir la presencia de al menos dos elementos copulativos: la unidad patrimonial y la consecución de un resultado injusto o inequitativo en caso de no aplicarse el levantamiento del velo; al respecto, véase Klein, Coffee y Partnoy (2010) p. 148.

10 Boldó Roda (2006) p. 387. La profesora Carmen Boldó define esta clase de fraude como la "utilización de la forma societaria como normativa de cobertura para eludir la aplicación de otra norma, la adecuada al caso, consiguiendo un resultado contrario al ordenamiento jurídico, injusto o dañoso para terceros”.
} 
pero añade que ambos términos admiten también un sentido más específico o técnico. Así, en un sentido técnico, el dolo civil es aquella conducta dirigida precisamente a causar daño por medio de maquinaciones engañosas, mientras que el fraude civil, aunque en la mayoría de los casos produce también un daño, tiene por fin principal eludir la aplicación de una regla desfavorable para quien realiza la conducta fraudulenta: en otras palabras, en el fraude civil la voluntad de dañar puede o no estar presente, y ello tendrá importancia únicamente para fines indemnizatorios; pero lo verdaderamente definitorio es la maniobra evasiva de una regla que no se quiere cumplir. Ahora bien, el fraude civil se lleva a cabo mediante la realización de un acto formalmente lícito, y por eso el profesor Domínguez Águila lo define como aquella conducta consistente en utilizar una norma para evadir otra, o dicho de otro modo, en "usar una regla jurídica para un fin ilícito o no tolerado por el derecho”; de ahí justamente que los actos fraudulentos parezcan lícitos desde un punto de vista exterior ${ }^{11}$.

Por otra parte, la doctrina suele distinguir entre dos maneras distintas de fraude: por un lado se encuentra el "fraude a la ley", que es una conducta que busca ampararse bajo una regla de derecho objetivo para evadir otra ${ }^{12}$; y por otro lado existe lo que se conoce como "fraude a los acreedores", por medio del cual se utiliza una institución legal para perjudicar a un tercero, como ocurre cuando el controlador disminuye substancialmente el capital de una sociedad para imposibilitar o dificultar gravemente que un acreedor social pueda realizar su crédito en el patrimonio de la compañía ${ }^{13}$. De todos modos, ya sea que se trate de un fraude a la ley o de un fraude a los derechos de terceros, en ambos casos se trata de una conducta ilícita que la ley debe sancionar. Teniendo presente lo anterior, es posible sostener que algunos casos de abuso de la personalidad jurídica constituyen situaciones arquetípicas de fraude civil: esta es la doctrina -ya clásica- de Rolf Serick, para quien existe un abuso cuando con ayuda de la persona jurídica se intenta burlar una ley, quebrantar obligaciones contractuales o perjudicar fraudulentamente a terceros ${ }^{14}$.

Ahora bien, aunque el Código Civil chileno no contiene una norma general que condene expresamente el fraude, sí contempla tácitamente el principio general de que el fraude todo lo corrompe -fraus omnia corrumpit-, en virtud del cual el fraude debe ser siempre sancionado y nunca admitido: por eso justamente el Código Civil lo castiga en

11 Véase Domínguez Águila (1992) pp. 82-84. Asimismo, véase Baltra (1935) pp. 155 y ss.

12 Refiriéndose al fraude a la ley, el profesor Enrique Alcalde, señala que los elementos que lo configuran son

(i) la ejecución de un acto o actos en sí mismos lícitos, (ii) la existencia de una ley defraudada y (iii) la intención de ejecutar el fraude, aunque subraya que la doctrina comparada está dividida en cuanto a la exigencia de este último requisito (AlCALde (2005) pp. 95-103).

13 Para una distinción entre fraude a la ley y fraude a los acreedores en el ámbito del derecho de sociedades, véase Cozian, Viandier y Deboissy (2005) p. 79. Sin perjuicio de lo anterior, cabe señalar que la doctrina está dividida acerca de la procedencia de distinguir entre fraude a la ley y fraude a los acreedores: así, algunos autores lo consideran irrelevante debido a que el fraude a los acreedores implica de todos modos violar una norma que obliga a respetar los derechos ajenos y puede por tanto encasillarse dentro del concepto de fraude a la ley (Domínguez Águila (1992) p. 89); mientras que otros opinan que el fraude a los acreedores no puede propiamente considerarse como un fraude a la ley, pues este último, al menos en sentido estricto, implica sustraerse de una prohibición legal o de una norma imperativa de orden público y, por tanto, acorde al interés general de la sociedad, mientras que el fraude a los acreedores implica incumplir una norma que protege más bien al interés particular de estos últimos (BARros Bourie (2006) pp. 652-654).

14 SERICK (1958) p. 242. 
numerosas y diversas disposiciones, siendo quizás la más conocida la del artículo 2.468, que establece la acción pauliana ${ }^{15}$. Lo cierto es que el fraude, por su propia naturaleza, debe entenderse universalmente prohibido en todos los sistemas legales incluso sin necesidad de disposición expresa, pues constituye una conducta cuyo objetivo es precisamente impedir que una norma produzca efectos; en otras palabras, el fraude es la negación misma del derecho, de modo que sería contradictorio que un ordenamiento jurídico lo admitiera siquiera parcialmente. A similar conclusión se ha llegado en Francia, donde se acepta generalmente el principio fraus omnia corrumpit, aunque ni el Código Civil ni el Código de Comercio lo contemplan explícitamente ${ }^{16}$. Sin perjuicio de lo anterior, otros ordenamientos más modernos han prohibido específicamente el fraude en materia civil, como se observa en el artículo 6.4 del Código Civil español, que establece que "los actos realizados al amparo del texto de una norma que persigan un resultado prohibido por el ordenamiento jurídico, o contrario a él, se considerarán ejecutados en fraude de ley y no impedirán la debida aplicación de la norma que se hubiere tratado de eludir".

Por otra parte, la sanción del fraude civil se desprende de su propia naturaleza, pues si el fraude consiste en escudarse en el cumplimiento de una norma para evadir otra, es lógico que tal sanción consista en la aplicación directa de la regla que se ha intentado evadir, para restablecer de esta manera el imperio del derecho. Así, cuando alguien realiza un acto fraudulento que produce daño a un tercero, este último podrá exigir que se prescinda del acto en virtud del cual se ha querido privarlo de sus derechos. Esta es, por lo demás, la solución particular que establece la ley chilena en algunos de los casos más característicos de fraude, como es el caso del artículo 2.468 del Código Civil, que consagra la acción pauliana o revocatoria ${ }^{17}$; o de los artículos 76 y siguientes de la Ley de Quiebras, que establecen las acciones paulianas concursales; o del artículo 1.723 inciso segundo del Código Civil, que dispone que el pacto de separación de bienes entre cónyuges "no perjudicará, en caso alguno, los derechos válida-

15 Véase Baltra (1935) pp. 162 y Domínguez Águila (1992) pp. 77-81.

16 Cozian, Viandier y Deboissy (2005) pp. 69-70.

17 Mucho se ha discutido en Chile acerca del efecto propio de la acción pauliana: para algunos se trata de la nulidad, en particular de la nulidad relativa, mientras que para otros se trata de la inoponibilidad. Claro Solar señala que la acción pauliana no produce la nulidad absoluta ni la relativa del acto impugnado, porque este no tiene ninguno de los vicios que acarrean nulidad; asimismo, considera que el tercero demandado puede evitar la revocación pagando al acreedor, y que en caso de que la revocación se realice efectivamente, ella tendrá lugar solo hasta concurrencia del total adeudado (Claro Solar (1979) pp. 626 y ss). Baltra, por su parte, estima que el efecto de la acción pauliana es la inoponibilidad, argumentando que ella no acarrea la anulación integral del acto, sino únicamente con respecto al tercero perjudicado por el fraude y solo en la medida en que lo exijan sus intereses (Baltra (1935) P. 162). También Manuel Vargas considera que la acción pauliana produce la inoponibilidad, y no la nulidad del acto impugnado: al respecto, aduce entre otras cosas que (i) el acto revocado es válido en sí mismo y no padece vicio alguno de nulidad; (ii) la acción pauliana solo puede pedirla un tercero ajeno al acto, y no una de sus partes, a diferencia de lo que ocurre con la nulidad; y (iii) la revocación no implica la invalidación total del acto, sino solo respecto del acreedor que la ejerce y por el monto adeudado al acreedor (Vargas (1949) pp. 366 y ss.). Alessandri, Somarriva y Vodanovich (Alessandri, Somarriva y Vodanovic (2004) p. 208) y (Abeliuk (2008) p. 779) son de la misma opinión; y Domínguez Águila señala que hoy parece haber acuerdo en que la acción pauliana implica una forma de inoponibilidad (Domínguez ÁGuila (1992) p. 90). A lo anterior cabe añadir que en el caso de las llamadas acciones paulianas concursales, los artículos 74, 76 y 77 de la actual Ley de Quiebras señalan expresamente que su efecto es la inoponibilidad. 
mente adquiridos por terceros respecto del marido o de la mujer" ${ }^{18}$. En definitiva, para determinar la sanción específica que debe aplicarse generalmente al fraude, conviene tener presentes las palabras de Baltra, para quien el acto fraudulento "es perfecto en sí mismo: reúne todas las condiciones de existencia y de validez requeridas para que el acto nazca a la vida del derecho y produzca en ella sus efectos. Mas, el vicio anida en la intención de ambas o de una sola de las partes y el fraude basta que exista para que el acto no tenga la eficacia que, dada su perfección, debió haber tenido: fraus omnia corrumpit"19.

Considerando lo anterior, como observa el profesor Ramón Domínguez Águila, la sanción del fraude no debe extenderse más allá de la restitución de sus derechos o facultades a quien ha sido afectado por el fraude, de modo que, en lo demás, el acto fraudulento debe conservarse, porque es un acto real, que no tiene defectos o imperfecciones, salvo la finalidad fraudulenta perseguida por su autor. De este modo, siguiendo por lo demás la doctrina de Baltra $^{20}$, el profesor Domínguez Águila concluye que la única sanción jurídica que permite ignorar el fraude sin ir más allá de la restitución de sus derechos al afectado es la inoponibilidad del acto fraudulento, pues, a diferencia de la nulidad, "no aniquila el acto inoponible, pero paraliza sus efectos en relación a quien está autorizado a alegarla"21. Asimismo, el profesor Jorge López Santa María, aun reconociendo que la ley chilena no establece una regla general y expresa en tal sentido, sostiene que el fraude civil es motivo de inoponibilidad del acto fraudulento a quienes se intentaba perjudicar ${ }^{22}$; y el profesor Enrique Barros considera que la sanción aplicable al abuso del derecho realizado en fraude a terceros es la inoponibilidad, agregando que el acto fraudulento no está afectado por vicio alguno de nulidad ${ }^{23}$.

Coherentemente con lo dicho en los párrafos precedentes, la jurisprudencia de algunos tribunales superiores de justicia chilenos ha venido sancionando en el último tiempo el fraude en materia de sociedades y grupos empresariales, declarando inoponibles los actos realizados en abuso de la personalidad jurídica y acudiendo a tal efecto al procedimiento judicial del levantamiento del velo. Así ocurrió en el caso "Catrilef Hernández, Salomón y otros con Pesca Cisne S.A.”, en que los controladores de un grupo empresarial intentaron aprovecharse de su estructura jurídica para imposibilitar que unos terceros perjudicados por una de las sociedades integrantes del grupo pudieran exigir indemnización de perjuicios extracontractuales en su contra, argumentando que en realidad la responsable era otra sociedad del mismo grupo ${ }^{24}$.

\footnotetext{
18 Respecto del pacto de separación de bienes efectuado en fraude a terceros y su sanción, véase PeñaIliLlo ArÉvalo (1983) pp. 21 y ss.

19 Baltra sigue en este punto la doctrina de diversos autores franceses, incluyendo especialmente a Bastian; véase BaLtra (1935) p. 156.

20 Baltra (1935) pp. 155 y ss.

21 Domínguez Águila (1992) p. 91.

22 López Santa María (2010) pp. 325-326.

3 Barros Bourie (2006) p. 647.

24 Corte de Apelaciones de Punta Arenas, Rol No 230-2007. Los hechos fueron los siguientes: la sociedad Pesca Cisne S.A. reclutó a un grupo de trabajadores chilenos para trasladarlos al extranjero y embarcarlos en el buque Maya V, propiedad de la sociedad española Alcimar S.A., a fin de realizar actividades pesqueras; posteriormente, el mencionado buque realizó una pesca ilícita en aguas australianas, por lo que todos sus tripulantes fueron apresados, detenidos, dejados en un recinto penitenciario, condenados y expulsados de Australia. En razón de lo anterior, los tripulantes reclutados en Chile demandaron de perjuicios a Pesca Cisne S.A., quien se
} 
Algo similar sucedió en el caso "Scharfstein S.A. con Browne Keeling y Cía. Ltda. y Emparanza Paiva, Margarita Juliana" 25 , en el cual una sociedad pretendió valerse de su derecho a constituir una filial y aportarle un bien raíz a fin de evitar su embargo; y también en el caso "Proinvest Promotora de Inversiones S.A. con Trends Ingeniería S.A. y Datun Chile S.A."26, en que un inmueble fue transferido por una sociedad a su filial, y posteriormente vendido por esta última a su representante legal, a fin de impedir que un acreedor de la matriz pudiera ejercer su derecho de prenda general sobre el mencionado inmueble.

Todos los casos de jurisprudencia antes citados involucran una situación de fraude civil, pues en ellos el deudor se acogió a una norma legal para realizar un acto jurídico formalmente lícito (acogerse a la normativa aplicable a los grupo de sociedades, realizar un aporte en sociedad o vender un activo a un representante legal), pero con el fin de evadir el cumplimiento de una disposición legal (la que impone la obligación de indemnizar los perjuicios extracontractuales producidos a un tercero, o la que establece el deber de respetar el derecho de prenda general de un acreedor sobre los bienes del deudor). Por lo anterior, en cada una de las situaciones descritas, el tribunal respectivo tuvo por inoponible el acto fraudulento ante los terceros a quienes se buscó perjudicar, aplicó directamente las normas jurídicas a los individuos que habían pretendido eludirlas mediante una instrumentalización abusiva de una sociedad, y desestimó en el caso concreto la separación patrimonial de las sociedades que los respectivos deudores habían utilizado para incumplir sus obligaciones hacia el acreedor, obligándolos a indemnizar los daños extracontractuales a los terceros perjudicados o embargando el inmueble, según el caso. En otras palabras, lo que hizo el tribunal fue prescindir en una situación específica de la personalidad jurídica de las sociedades de las cuales se había abusado mediante la aplicación de la técnica judicial del levantamiento del velo, sin perjuicio de lo cual tales sociedades mantuvieron plena validez para todos los efectos legales, tanto entre los socios como frente a los terceros no perjudicados por el fraude ${ }^{27}$.

\section{EL ABUSO DE LA PERSONALIDAD JURÍDICA COMO ABUSO DEL DERECHO}

La regla general en el campo de las relaciones humanas es y debe ser la responsabilidad personal por las propias obligaciones: por eso, en el ámbito del derecho privado, una obli-

excepcionó alegando que en realidad ella solo había prestado servicios de reclutamiento a favor de un tercero Alcimar S.A.- , y que por tanto no era responsable de la pesca ilícita ni de los consiguientes perjuicios causados a los demandantes. Sin embargo, la corte acogió los argumentos de los demandantes, quienes fundaron su pretensión en el hecho de que Pesca Cisne S.A. y Alcimar S.A. participaban en un mismo conglomerado y conformaban en realidad una misma empresa, y que sus controladores habían abusado de la personalidad jurídica de las distintas compañías involucradas para burlar los derechos de terceros. Como consecuencia de lo anterior, el tribunal condenó a Pesca Cisne S.A. a indemnizar a los tripulantes del Maya V por los daños extracontractuales causados.

25 Corte de Apelaciones de Santiago, Rol No 771-2010

26 Corte de Apelaciones de Santiago, Rol Nº 6273-2010

27 Entre los autores chilenos que consideran aplicable el levantamiento del velo en casos de fraude a la ley o a los acreedores se encuentran Lyon (2003) p. 65; Aguad (2002) p. 311; López Díaz (2003) p. 288; y AlCalde (2005) p. 100. Por su parte, Álvaro Puelma considera que si el abuso de la personalidad jurídica incide en perjuicio de los acreedores, hay que atenerse a las reglas relativas a las acciones revocatorias, incluyendo la pauliana civil y las concursales (Puelma (2003) p. 108). 
gación de dar, hacer o no hacer genera un derecho subjetivo correlativo en virtud del cual el acreedor puede exigir al deudor el cumplimiento de lo que le debe. En este contexto, la responsabilidad limitada de los socios de algunos tipos de sociedades constituye una cierta excepción, pues significa un beneficio por el cual los socios no responden de las obligaciones contraídas mediante la persona jurídica que han constituido sino hasta el monto de su aporte. A raíz de esto último, es posible afirmar que todas las personas tienen derecho a constituir compañías con patrimonio separado y de cuyas deudas respondan limitadamente, y a estructurar sus relaciones jurídicas con los demás sujetándose a las normas propias del derecho societario; sin embargo, el derecho a separar patrimonios y a responder limitadamente por las deudas sociales es susceptible de abusos que el ordenamiento jurídico debe sancionar.

Puede decirse que abusa de la personalidad jurídica de una sociedad o de sus atributos esenciales quien la utiliza para obtener fines adversos a aquellos que el legislador tuvo en cuenta al establecerla y provoca así su desnaturalización, o quien se vale de ella de manera opuesta a las reglas de la buena fe, la moral o las buenas costumbres: en definitiva, quien ejerce su derecho a someterse al régimen societario de forma antijurídica, esto es, contrariando el ordenamiento actualmente vigente considerado de manera integral. En relación con lo anterior, cabe señalar que todas las situaciones típicas de abuso del derecho pueden darse en materia de sociedades, incluyendo casos como el ejercicio de un derecho con el solo propósito de causar daño a otra persona, el ejercicio de un derecho que genera una extrema desproporción entre el interés del titular y el perjuicio causado a un tercero, el ejercicio de un derecho adquirido de mala fe, el ejercicio de un derecho que implica una conducta que contradice los actos propios, o el ejercicio de un derecho que significa desviar el fin para el cual este ha sido reconocido por la ley o el contrato, particularmente cuando se lo utiliza con un fin fraudulento ${ }^{28}$.

Considerando que, en materia de sociedades, uno de los casos más frecuentes de abuso del derecho es aquel que se realiza mediante la desviación de su fin para la producción de un fraude, es fundamental tener presente que la atribución de personalidad jurídica a las sociedades y la consiguiente separación entre el patrimonio social y el personal de los socios ha sido concebida legalmente con una doble finalidad.

En primer lugar, ella tiene por objeto posibilitar efectivamente la separación entre el patrimonio de los socios y la sociedad y, en algunos tipos de sociedades, limitar la responsabilidad de aquellos por las obligaciones de esta, para promover así la creación y desarrollo de empresas ${ }^{29}$. De ahí que sea legítimo constituir sociedades incluso para el solo efecto de

28 Respecto de las distintas situaciones en que puede darse un abuso del derecho, véase Barros Bourie (1996) pp. 632-646. En cuanto a la relación entre el levantamiento del velo y el abuso del derecho, el profesor Enrique Barros señala que, desde el punto de vista de la responsabilidad civil, "el levantamiento del velo es un ámbito de aplicación de la doctrina del abuso del derecho potestativo a separar actividades empresariales en sociedades o empresas unipersonales que limitan la responsabilidad de los agentes afectados" (Barros Bourie (2006) p. 207). Cabe agregar que algunas legislaciones han incorporado expresamente en el último tiempo la doctrina del abuso del derecho; así, el artículo 1071 del Código Civil argentino dispone: "El ejercicio regular de un derecho propio o el cumplimiento de una obligación legal no puede constituir como ilícito ningún acto. La ley no ampara el ejercicio abusivo de los derechos. Se considerará tal al que contraríe los fines que aquella tuvo en mira al reconocerlos o al que exceda los límites impuestos por la buena fe, la moral o las buenas costumbres”.

29 Así, comentando el texto de la ley 3.918 de 1923 sobre Sociedades de Responsabilidad Limitada, su redac- 
limitar la responsabilidad personal de $\operatorname{los} \operatorname{socios}^{30}$, sin perjuicio de lo cual, para gozar del beneficio de la responsabilidad limitada, los socios deben haber establecido una compañía con existencia real, que persiga ciertos fines económicos propios y distintos de aquellos que los socios persiguen en su patrimonio personal, de modo que no se trate de una sociedad meramente simulada o ficticia ${ }^{31}$. Por lo demás, de la definición misma del artículo 2.053 del Código Civil se desprende que para que la sociedad tenga existencia real los socios deben haber acordado el desarrollo de alguna actividad que pueda reportarles ganancias: "la sociedad o compañía es un contrato en que dos o más personas estipulan poner algo en común con la mira de repartir entre sí los beneficios que de ello provengan" 32 . En relación con lo anterior, debe estimarse que la causa de las obligaciones de los socios consiste en las obligaciones esenciales asumidas correlativamente por los demás socios, es decir, el aporte en sociedad y la participación en los riesgos del negocio societario: así se deduce de la mencionada definición del artículo 2053 del Código Civil, y esa es precisamente la razón por la cual el artículo 2055 del mismo código dispone que la sociedad es inexistente si cada uno de los socios no realiza un aporte social, o si no hay participación en los beneficios, lo cual es coherente con el hecho de que los contratos que carecen de causa son inexistentes ${ }^{33}$.

En segundo lugar, la separación entre el patrimonio social y el personal de los socios ha sido concebida con el objeto de deslindar el patrimonio sobre el cual los acreedores sociales y los acreedores personales pueden ejercer su derecho de prenda general contra la sociedad y los socios, respectivamente. Así, la separación patrimonial busca proteger los derechos de los acreedores sociales, ofreciéndoles un patrimonio cierto y determinado en el cual puedan hacer efectivos sus créditos contra la compañía, con independencia de las pretensiones de los acreedores personales de los socios ${ }^{34}$; y, al mismo tiempo, la separación patrimonial intenta salvaguardar a los acreedores personales de los socios poniendo a su disposición un patrimonio en el cual puedan hacer valer sus derechos sin tener que disputarlos

tor, don Luis Claro Solar, decía abrigar la confianza de que esta ley "ha de contribuir al desarrollo industrial del país, facilitando la implantación de muchos negocios útiles" (Claro Solar (1923) p. 17).

30 Así lo han decidido expresamente, por ejemplo, los tribunales de Estados Unidos (Bainbridge (2002) p. 128), Inglaterra (Davis (2008) p. 208) y Francia (Ripert y Roblot (2009) p. 121), entre otros.

31 Véase Ripert y Roblot (2009) p. 121, y Nissen (2010) pp. 87 y ss.

32 Manóvil señala incluso que la independencia jurídica de la sociedad como sujeto de derecho presupone su autonomía patrimonial y económica en grado suficiente para el desarrollo de una actividad económicamente productiva y, por tanto, capaz de generar utilidades a quienes la conforman (Manóvil (1998) pp. 568 y 569).

33 Diversos autores consideran que la participación en las ganancias o pérdidas de la sociedad constituye la causa como elemento esencial de la sociedad: así, Manóvil apunta que "correr el riesgo en común constituye, en el plano jurídico, la causa-fin de la sociedad” (Manóvil (1998) p. 569); por su parte, al comentar el artículo 1.832 del Código Civil francés, que establece que el aporte de los socios se efectúa "en vistas a compartir los beneficios o disfrutar de las economías que puedan producirse", Ripert y Roblot señalan que la ley ha indicado el objetivo perseguido por los socios y, por tanto, ha precisado la causa final de la sociedad como acto jurídico (Ripert y Roblot (2009) pp. 15-16). En nuestro derecho, Enrique Alcalde identifica la causa final de la sociedad con el interés social, al cual define como "el objetivo de desarrollar, en conjunto, una cierta actividad en vistas de repartir entre sí los beneficios pecuniarios que de ello provengan", y cita posteriormente un pasaje de Carnelutti en que este señala que "la causa está contenida en el ejercicio común de una actividad económica para dividir las utilidades, en la comunión de fin calificada” (AlCalde (2008) pp. 40-43).

34 Nissen (1998) p. 121; NiSSEN (2010), p. 81. 
con los acreedores sociales, en lo que constituye una aplicación del principio que la doctrina estadounidense reciente ha denominado entity shielding 35 .

Existe jurisprudencia chilena que, en el último tiempo, ha vinculado explícitamente la aplicación de la doctrina del levantamiento del velo con el abuso del derecho. Así, en el caso "Scharfstein S.A. con Browne Keeling y Cía. Ltda. y Emparanza Paiva, Margarita Juliana”, el tribunal estimó que los demandados habían constituido la sociedad Inmobiliaria Loreto S.A. para el solo objeto de aportarle un inmueble y evitar así que este fuera embargado a favor de un acreedor personal de los socios, mientras que en el caso "Proinvest Promotora de Inversiones S.A. con Trends Ingeniería S.A. y Datun Chile S.A.” la corte consideró que un bien raíz había sido aportado a una filial y posteriormente había sido vendido al representante legal de esta última con la finalidad de eludir o quitar toda eficacia a las medidas dictadas por el juez para proteger a un acreedor social de la matriz. En ambas situaciones se trató del ejercicio de un derecho (constituir una sociedad, aportarle bienes o vender parte de su activo a un tercero), pero de manera abusiva, pues lo que se hizo fue desviarlo hacia un fin ilícito (defraudar a un acreedor personal o social, según el caso). Por su parte, en el caso "Consorcio Allianz de Seguros Generales S.A. con Sociedad Naviera Ultragas Ltda. y Ultramar Agencia Marítima Ltda.”, la Corte Suprema estimó que la conducta de la demandada implicaba exceder los límites de la buena fe y abusar del derecho contradiciendo los actos propios, ya que pretendía evitar el pago de una indemnización de perjuicios extracontractuales apelando a una absoluta separación entre ella y su filial, en circunstancias que sus actuaciones habían manifestado o al menos aparentado una substancial identidad personal y económica e incluso una participación conjunta de ambas compañías en las etapas de negociación y ejecución del contrato, generando una justificable confusión en la demandante.

Respecto de los casos antes citados, cabe advertir que no hay contradicción en analizarlos simultáneamente bajo la doctrina del abuso del derecho y la doctrina del fraude civil, ya que por lo común se da entre ellas una relación de medio a fin: así ocurre cuando se realiza un fraude mediante un abuso del derecho, que es justamente lo que sucedió en los casos analizados más arriba ${ }^{36}$.

\section{EL ABUSO DE LA PERSONALIDAD JURÍDICA MEDIANTE UNA SIMULACIÓN ILÍCITA O FRAUDULENTA}

También la doctrina de la simulación ilícita puede servir en algunas oportunidades como fundamento para la aplicación del levantamiento del velo en el derecho chileno. Se

35 Un análisis del concepto de entity shielding y de su desarrollo histórico puede encontrarse en el profundo y acabado estudio de HANSMANN, KRAAKMAN Y SQUIRE (2006).

36 En todo caso, debe tenerse presente que la doctrina trata ambas instituciones separadamente: así, algunos autores reservan el tratamiento del fraude -al menos en sentido estricto- únicamente para el denominado "fraude a la ley", y estudian el llamado "fraude a los acreedores" más bien con motivo del abuso del derecho (BARRos Bourie (2006) pp. 650-654; Boldó Roda (2006) pp. 213-214); mientras que otros analizan el fraude a los acreedores y el abuso del derecho en sede diferente, no obstante reconocer una estrecha relación entre ambas instituciones (Domínguez Águila (1992) p. 88). Por otra parte, entre los autores chilenos que consideran el abuso del derecho como posible fundamento para aplicar el levantamiento del velo societario están AGUAD (2002) p. 311, con mención especial a la doctrina de los actos propios; y PUga VIaL (2011) pp. 59 y ss. 
entiende que hay simulación cuando una o más personas emiten una declaración de voluntad que no refleja verdaderamente la realidad, de modo tal que los efectos de un acto aparente "son modificados o completamente suprimidos por otro acto destinado a permanecer en secreto" 37 ; ahora bien, la simulación es ilícita o fraudulenta cuando perjudica a terceros, incluso si la intención de las partes no ha sido provocar tal daño ${ }^{38}$. Conforme a lo anterior, cuando se simula una transferencia de bienes a un tercero para sustraerlos del alcance de un acreedor, este último tiene acción de simulación para que se prescinda del acto simulado y se establezca que los bienes transferidos continúan en el patrimonio del deudor, de donde se desprende que dicha acción hace posible, en definitiva, que se determine cuáles son los bienes sobre los cuales el acreedor tiene efectivamente derecho de prenda general ${ }^{39}$.

En materia de sociedades, la voluntad de asociarse debe ser sincera y no meramente simulada, entendiéndose que se incumple este requisito cuando la constitución de la compañía (acto aparente) disimula otro contrato que es el verdaderamente querido por las partes (acto secreto), como por ejemplo una donación que busca evadir las leyes que protegen la legítima, o un crédito que busca exceder el interés máximo legal. Asimismo, la sociedad es simulada cuando no es más que una fachada para enmascarar las actuaciones de una sola persona, lo que muchas veces se refleja en la ausencia de affectio societatis -es decir, de voluntad real de conformar una sociedad-, en la omisión de la obligación de realizar un aporte, o en la realización de un aporte puramente ficticio por uno o más socios aparentes ${ }^{40}$. En algunas ocasiones tiene lugar la simulación por interpósita persona, como sucede cuando una sociedad no actúa en interés propio, sino en interés de uno o más socios o de un tercero ${ }^{41}$; lo cual debe ciertamente relacionarse con la doctrina anglosajona del alter ego, en cuya virtud puede determinarse en ciertos casos que una sociedad no actúa por cuenta propia sino por cuenta de su controlador y que, en consecuencia, este último es personalmente responsable de las deudas contraidas en su interés por la sociedad ${ }^{42}$. No obstante lo anterior, debe recordarse que, para que la simulación sea ilícita o fraudulenta y pueda eventualmente dar lugar al levantamiento del velo, es necesario que provoque un perjuicio injusto a un tercero ${ }^{43,44}$.

\footnotetext{
37 López Santa María (2010) p. 327.

38 Claro Solar (1979) p. 648.

39 Claro Solar (1979) pp. 648-649.

40 Respecto de la simulación en materia de sociedades, véase Merle (2010) pp. 76-78.

41 Cozian, Viandier y Deboissy (2005) p. 73.

42 Bainbridge (2002) pp. 128-130.

43 En el caso "Scharfstein S.A. con Browne Keeling y Cía. Ltda. y Emparanza Paiva, Margarita Juliana” (Corte de Apelaciones de Santiago, Rol N 771-2010), aunque la Corte de Apelaciones de Santiago aplicó el levantamiento del velo desde la perspectiva del abuso del derecho, no puede negarse que hubo también presente un factor de simulación. Entre los elementos que la corte tuvo en cuenta para prescindir de la personalidad jurídica de la sociedad Inmobiliaria Loreto S.A., estaba el hecho de tratarse una sociedad "de papel", es decir, sin existencia real ni vida propia. En realidad, los socios nunca tuvieron una voluntad verdadera de formar una sociedad (affectio societatis), como quedaba por lo demás acreditado por el hecho de que tal sociedad no explotaba ni podía explotar actividad comercial alguna, pues no se habia cumplido respecto de ella con algunas de las solemnidades legales de constitución ni se habia realizado el trámite de inicio de actividades ante el Servicios de Impuestos Internos a pesar del transcurso de años desde el otorgamiento de la respectiva escritura.

44 Entre los autores chilenos que consideran la simulación ilícita como un posible fundamento para enfrentar el abuso de la personalidad jurídica se encuentran Puelma (2003) p. 108; Aguad (2002) p. 311; Puga Vial
} 


\section{EL ABUSO DE LA PERSONALIDAD JURÍDICA Y EL PRINCIPIO DE LA BUENA FE}

El principio de la buena fe juega un rol preponderante en la aplicación del levantamiento del velo. En materia contractual, el artículo 1.546 del Código Civil dispone que "los contratos deben ejecutarse de buena fe, y por consiguiente obligan no solo a lo que en ellos se expresa, sino a todas las cosas que emanan precisamente de la naturaleza de la obligación, o que por la ley o la costumbre pertenecen a ella”.

La buena fe significa honrar todos aquellos deberes conforme a los cuales una parte tiene derecho a esperar que la otra actúe en razón de la naturaleza de sus relaciones recíprocas, la ley o la costumbre. Es cierto que las partes de un contrato persiguen o pueden perseguir intereses contrapuestos, pero también es cierto que el contrato es un mecanismo al que ellas acuden para satisfacer ciertos intereses personales que no podrían satisfacer individualmente, al menos de manera tan eficiente como por medio del contrato; y por eso el principio de la buena fe exige que cada parte cumpla recta, leal y honestamente sus obligaciones hacia la otra, de modo que ambas puedan alcanzar aquellos objetivos que se han propuesto al contratar, lo que por lo demás es aplicable no solo a la etapa de ejecución, esto es, de cumplimiento del contrato, sino también a los tratos preliminares, a la celebración misma del acuerdo, a su interpretación, su terminación e incluso a las relaciones postcontractuales de las partes ${ }^{45}$.

Por el contrario, la mala fe implica oponer deliberadamente tropiezos a la otra parte durante cualquiera de las etapas antes mencionadas, para impedir o dificultar que pueda ejercer sus derechos o satisfacer los intereses por los cuales ha contratado. En realidad, el derecho no puede proteger a la persona que, luego de contraer una obligación, realiza actos que impiden o dificultan injustamente que el titular del derecho correlativo pueda satisfacer sus legítimos intereses. Así ocurre, por ejemplo, cuando se pide un préstamo y posteriormente se ceden activos substanciales a una sociedad de la cual el deudor es controlador para disminuir o anular la prenda general del acreedor: tal conducta y cualquier otra análoga constituyen actos de mala fe, y son por consiguiente contrarios a la disposición del artículo 1.546 del Código Civil. En relación con lo anterior, cabe advertir que el derecho de sociedades puede ofrecer ciertas oportunidades a la mala fe, especialmente a aquella que se expresa mediante un formalismo jurídico abusivo, pues la separación entre el patrimonio social y el personal de los socios facilita notablemente las transferencias de activos que, no obstante parecer lícitas desde un punto de vista exterior, en realidad tienen por fin perjudicar a terceros.

En este contexto, cabe señalar que el procedimiento judicial del levantamiento del velo constituye un eficaz instrumento para que el juez vele por el respeto a la buena fe en el

(2011) pp. 59 y ss.; y Mereminskaya (2003) p. 26. Esta última autora cita los casos "Banco Sudameris con Varas Espejo" (RDJ Tomo XC, 1993, N 1) y "Hernández Villega y otros con Maturana Lanza" (RDJ Tomo XCVIII, 2001, $\mathrm{N}^{\circ} 1$ ).

45 En cuanto a la vigencia del principio de la buena fe a las etapas anterior y posterior a la celebración misma del contrato, véase López Santa María (2010) pp. 348-360, y Corral (2010) pp. 69-76. Este último distingue entre lo que denomina "extensión contractual horizontal" del principio de buena fe, que se refiere a cómo deben conducirse las partes antes y después del contrato, y lo que llama "extensión contractual vertical" del principio de buena fe, que alude a las cosas a que obligan los contratos. 
ámbito societario. Así, en el caso "Consorcio Allianz de Seguros Generales S.A. con Sociedad Naviera Ultragas Ltda. y Ultramar Agencia Marítima Ltda.”, la demandada había participado activamente en la negociación y ejecución de un contrato, pero al ser demandada por incumplimiento, se excepcionó argumentando que en realidad el contrato había sido suscrito por su filial; la Corte Suprema, sin embargo, aplicó el levantamiento del velo, señalando que este permite privilegiar el principio de la buena fe, que podría verse sobrepasado en virtud de una interpretación "puramente formalista" de las obligaciones de las partes, y determinó en consecuencia que la demandada era directamente responsable del incumplimiento contractual. Por su parte, en el caso "Scharfstein S.A. con Browne Keeling y Cía. Ltda. y Emparanza Paiva, Margarita Juliana”, la Corte de Apelaciones de Santiago estimó que el principio de la buena fe autoriza a la judicatura "para ir más allá de la ficción que constituye la persona jurídica y descubrir al que se esconde bajo su sombra para defraudar a su acreedor", de modo de determinar quién es el verdadero responsable de los hechos que han causado daño, prescindiendo incluso de las meras formalidades exteriores.

Ahora bien, aunque en todos o casi todos los casos en que se ha acogido judicialmente la doctrina del levantamiento del velo se cita como fundamento el principio de la buena fe, cabe advertir que nunca se alude a tal principio como fundamento único, sino en conjunto con otro, como la comisión de un fraude o un abuso del derecho ${ }^{46}$.

\section{EL ABUSO DE LA PERSONALIDAD JURÍDICA Y LA CAUSA ILÍCITA}

Algunos autores consideran posible justificar el levantamiento del velo corporativo en la doctrina de la causa ilícita: así, el aporte de un activo a una sociedad para burlar los derechos del acreedor personal de un socio tendría causa ilícita ${ }^{47}$. Con todo, esta posición parece en principio contradecir la idea clásica de causa propuesta por Domat y Pothier, y posteriormente adoptada por el Código Civil chileno, que consiste en el concepto de causa final conforme a la doctrina filosófica de Aristóteles y los escolásticos, esto es, en el fin objetivo e intrínseco del acto, y no en la intención subjetiva del agente, que es extrínseca al acto jurídico ${ }^{48}$. Considerada la causa como fin intrínseco del acto, ella es siempre la misma con prescindencia de las intenciones subjetivas de las partes, de modo que cuando un socio aporta un activo a una sociedad, la causa de tal aporte consiste invariablemente en las obligaciones esenciales asumidas correlativamente por los demás socios (el aporte en sociedad y la participación en los riesgos del negocio societario), independientemente del móvil subjetivo e incluso si este ha sido burlar los derechos de terceros; por consiguiente, el aporte en sociedad efectuado por un socio para burlar los derechos de un acreedor personal no tendría desde este punto de vista causa ilícita, sino que debiera atacarse más bien acudiendo a la doctrina del fraude civil.

46 En este sentido, el profesor Ignacio Urbina considera que la simple mención al principio de la buena fe parece incompleta o excesivamente amplia para justificar con precisión la desestimación de la personalidad jurídica (Urbina (2011) P. 168).

47 Sobre la causa ilícita como fundamento de la aplicación del levantamiento del velo, véase por ejemplo MEREMINSKAYA (2003) p. 25.

$48 \mathrm{Al}$ respecto, véase Claro Solar (1979) pp. 308-309. 
Sin embargo es necesario tener presente que, incluso entre los seguidores de la doctrina de la causa como fin intrínseco del acto jurídico, hay quienes extienden en ciertos casos el concepto de causa al de móvil subjetivo, y consideran anulables por causa ilícita los contratos bilaterales que, aunque teniendo por objeto prestaciones lícitas, han sido celebrados con un móvil subjetivo ilícito, con tal que este último haya sido compartido por ambas partes del contrato. Así, tratando de la causa en los actos jurídicos, Claro Solar se refiere al ejemplo arquetípico del arrendamiento de un inmueble para ser usado como casa de prostitución: en tal caso, las prestaciones recíprocas de las partes (entregar el goce del inmueble y pagar la renta) son intrínsecamente lícitas, pero el móvil subjetivo de las partes (explotar el inmueble como casa de prostitución) es contrario a la moral y las buenas costumbre y, por tanto, ilícito; y si el móvil subjetivo ilícito ha sido compartido por ambos contratantes, entonces el contrato tendría causa ilícita ${ }^{49}$. Aplicando la regla anterior, un aporte en sociedad o una distribución de dividendos realizada con ánimo de burlar los derechos de un acreedor tendría causa ilícita si la intención de defraudar hubiera sido compartida por el socio y la compañía.

\section{EL ABUSO DE LA PERSONALIDAD JURÍDICA Y LA APLICACIÓN DE LAS REGLAS DE LA RESPONSABILIDAD EXTRACONTRACTUAL}

En principio pareciera que el levantamiento del velo de una sociedad puede asimismo aplicarse acudiendo a las reglas de la responsabilidad extracontractual, en virtud de las cuales cabe en ciertos casos imputar al controlador la responsabilidad por los hechos realizados formalmente por la sociedad controlada. Como observa el profesor Enrique Barros, así ocurre cuando se atribuye un delito directamente al controlador que conduce de hecho los negocios de la sociedad controlada, en términos tales que esta última o bien carece de la autonomía real y funcional propia de las personas jurídicas independientes, o bien es utilizada como un mero instrumento técnico para la obtención de los fines del controlador, de quien es dependiente y cuyas instrucciones sigue; sin embargo, cabe advertir que, como señala el propio profesor Barros, en los casos de responsabilidad extracontractual del controlador no es necesario el levantamiento del velo en un sentido estricto, ya que el controlador no responde por los hechos de la sociedad controlada, sino por los propios ${ }^{50}$. Un caso típico de abuso de la personalidad jurídica puede ser el de una sociedad que ha sido dotada por sus socios de un capital desproporcionadamente bajo teniendo en cuenta sus necesidades de funcionamiento, las actividades que desarrolla y los riesgos que estas involucran para terceros ("infracapitalización"): dado que el derecho chileno no exige sino excepcionalmente un capital mínimo a las sociedades, un tercero afectado por un delito o cuasidelito civil

49 Claro Solar (1979) pp. 348-353, con citas a la doctrina de Capitant, Josserand y Savatier, como también a la jurisprudencia francesa e italiana. Debe advertirse que la extensión de la doctrina de la ilicitud de la causa a los casos en que existe un móvil subjetivo ilícito compartido por ambos contratantes, ha hecho a algunos autores pensar que nuestro derecho no concibe la causa únicamente como fin intrínseco del acto, sino también como móvil subjetivo, pretendiendo entonces la existencia de un régimen dual; así, León Hurtado (1990) p. 30 .

50 Barros Bourie (2006) pp. 208-210. 
cometido por una sociedad infracapitalizada podría verse en la situación de que esta última no tenga el patrimonio suficiente como para responder por los daños extracontractuales causados; en tal caso, y conforme a las reglas generales de la responsabilidad extracontractual, podría reconocerse a la víctima acción para perseguir la responsabilidad de los socios que han capitalizado de modo tan deficiente la sociedad que ha causado el daño.

\section{LA INOPONIBILIDAD POR ABUSO DE LA PERSONALIDAD JURÍDICA}

Es posible pedir el levantamiento del velo societario en Chile acudiendo a los distintos fundamentos expresados más arriba, para lo cual deben ejercerse las acciones que en cada caso correspondan según la naturaleza del fundamento invocado. Sin embargo, la manera más propia de calificar el abuso de la personalidad jurídica es como un fraude, generalmente perpetrado mediante un abuso del derecho, de modo que la sanción más adecuada contra el mismo es la inoponibilidad: en realidad, la acción de inoponibilidad por abuso de la personalidad jurídica debiera considerarse principalmente como una acción de inoponibilidad por fraude ${ }^{51}$. En cuanto a la naturaleza del fraude civil, a la procedencia de la inoponibilidad como sanción adecuada al mismo, a la opinión de distintos autores chilenos y a la jurisprudencia dictada en la materia, nos remitimos a lo dicho más arriba, especialmente en el capítulo 2.

Teniendo presente lo anterior, toda persona debe estimarse titular del derecho a exigir que se declare judicialmente que le son inoponibles los actos perpetrados en su perjuicio mediante un abuso de la personalidad jurídica de una sociedad; así se concluye, por lo demás, de los fallos de los tribunales superiores de justicia aludidos precedentemente. A continuación se revisará la forma como dicha inoponibilidad debiera hacerse valer en la práctica en Chile.

\section{ACCIÓN Y EXCEPCIÓN DE INOPONIBILIDAD POR ABUSO DE LA PERSONALIDAD JURÍDICA}

Desde el punto de vista procesal, debe admitirse la existencia de una acción ordinaria de naturaleza declarativa en virtud de la cual pueda pedirse que se prescinda de la personalidad jurídica de una sociedad de cuya estructura se ha abusado, de modo que los efectos jurídicos que se ha intentado vulnerar o evadir mediante la comisión de un acto fraudulento se atribuyan directamente a quienes han cometido o permitido tal abuso, ya sea uno de los socios, un administrador con poderes para controlar de hecho la compañía, o una o más sociedades del mismo grupo empresarial.

Así, en el caso "Catrilef Hernández, Salomón y otros con Pesca Cisne S.A.", el considerando sexto del respectivo fallo de la Corte de Apelaciones de Punta Arenas constata que la demandante -tanto en la demanda como en la apelación- "esgrimió como argumento principal que la demandada hizo abuso del ropaje formal de la personalidad jurídica para evadir la ley y no responder de los perjuicios" causados a la demandante; por su parte, en el considerando décimo segundo del fallo, luego de haber acreditado el abuso de la personali-

51 Respecto de las acciones de inoponibilidad por fraude, véase BaLtra (1935) pp. 155 y ss. 
dad jurídica, la corte determinó que "es permitido entonces a los sentenciadores utilizar la técnica del levantamiento del velo". Al respecto, cabe observar que luego de un cuidadoso examen de las circunstancias del caso, el tribunal determinó que la demandada y sus sociedades relacionadas constituían en los hechos una misma empresa, y que sus socios y accionistas cometieron un abuso del derecho al utilizar la estructura formal de la personalidad jurídica para evadir la reparación de un daño causado a la demandante que correspondía resarcir. Por consiguiente, la corte atribuyó a la demandada la obligación de responder por los perjuicios extracontractuales sufridos por la demandante, no obstante que desde un punto de vista estrictamente formal ellos habían sido causados no por la demandada sino por otra sociedad del mismo grupo. En otras palabras, lo que hicieron los jueces fue prescindir en el caso concreto de la separación personal y patrimonial de las distintas sociedades involucradas para evitar la comisión de un perjuicio abusivo mediante la instrumentalización de un grupo de sociedades ${ }^{52}$.

Ahora bien, aunque debe reconocerse la existencia de una acción declarativa ordinaria de inoponibilidad por abuso de la personalidad jurídica, no hay inconveniente alguno en que dicha inoponibilidad se pida por una vía judicial distinta: así, es perfectamente concebible que en los hechos ella se haga valer por vía de defensa, esto es, como una excepción opuesta contra quien demande judicialmente el cumplimiento de una obligación originada mediante un abuso de la forma societaria. Por ejemplo, en el juicio "Scharfstein S.A. con Browne Keeling y Cía. Ltda. y Emparanza Paiva, Margarita Juliana”, llevado ante la Corte de Apelaciones de Santiago, la ejecutante opuso excepción de dolo contra una tercerista de dominio a fin de obtener el levantamiento del velo societario de esta última. En este caso, la corte reconoció que la tercerista era una sociedad cuyos accionistas eran los propios demandados en el juicio principal, quienes realizaron maniobras engañosas e interpusieron una tercería de dominio para burlar al acreedor y mantener un inmueble embargado en el patrimonio de la sociedad ejecutada. Comprobado entonces un abuso de la personalidad jurídica para perjudicar al acreedor, la corte decidió en el considerando décimo de su fallo que debía levantarse el velo de la tercerista y determinarse que el verdadero dueño del inmueble embargado era la sociedad ejecutada y no la tercerista de dominio.

La inoponibilidad por abuso de la personalidad jurídica puede también pedirse mediante su acumulación a una acción principal de distinta naturaleza, con motivo de un incidente, o en general con ocasión de cualquier procedimiento en que ello resulte necesario para obtener la debida protección de una persona a quien se ha buscado perjudicar injustamente. En este sentido, en el juicio ordinario por cobro de pesos "Proinvest Promotora de Inversiones S.A. con Trends Ingeniería S.A. y Datun Chile S.A.", llevado ante la Corte de Apelaciones de Santiago, la demandante pidió la ampliación del embargo sobre un inmueble que había sido propiedad de la sociedad demandada, pero que durante el juicio había sido transferido a una filial de la demandada y posteriormente al administrador común de ambas sociedades. El tribunal consideró que se trataba de maniobras efectuadas de mala fe por el representante de la sociedad deudora, quien había abusado de la personalidad jurídi-

52 Para una breve descripción de los hechos del caso "Catrilef Hernández, Salomón y otros con Pesca Cisne S.A.”, véase la nota 24 anterior. 
ca de las sociedades que representaba a fin de perjudicar a su acreedor. Como consecuencia de lo anterior, la corte aplicó la doctrina del levantamiento del velo, determinó que las sucesivas transferencias eran inoponibles a la demandante y accedió a la petición de que se trabara el embargo del inmueble en cuestión.

En cuanto a la forma de pedirse la inoponibilidad por abuso de la personalidad jurídica, y dado el escaso desarrollo que la doctrina del levantamiento del velo ha tenido en nuestro país, es especialmente interesante tener presente el derecho comparado. Así, comentando el artículo 54 de la Ley de Sociedades Comerciales argentina, Nissen sostiene que la inoponibilidad por abuso de la personalidad jurídica de una sociedad puede perseguirse mediante el ejercicio de una acción ordinaria, autónoma y de naturaleza meramente declarativa, sin perjuicio de lo cual puede pedirse de manera accesoria a otra acción o por vía de incidente ${ }^{53}$. Por su parte, Manóvil observa que la mencionada inoponibilidad puede plantearse tanto por vía de acción como por vía de defensa, indicando que "deberá admitirse la discusión sobre la inoponibilidad de la personalidad jurídica de la sociedad en cualquier tipo de proceso de conocimiento, aun como complemento de una acción principal que verse sobre la relación substancial cuya imputación se pretenda eventualmente extender o trasladar a otro sujeto" 54 . Asimismo, Roitman, Aguirre y Chiavassa sostienen que la inoponibilidad puede invocarse como acción o excepción, y que cuando se ejerza como acción, su naturaleza será necesariamente declarativa y accesoria, ya que siempre se ejercerá conjuntamente con un reclamo principal que busque imputar los efectos de una determinada actuación a quienes han abusado de una sociedad ${ }^{55}$.

\section{El LeVANTAMiento DEL Velo PUEDE PRACTICARSE SIN NECESIDAD DE UN JUiCiO DECLARATIVO PREVIO}

Por otra parte, considerando que el levantamiento del velo societario tiene lugar ordinariamente como consecuencia de un fraude, la acción de inoponibilidad por abuso de la personalidad jurídica debe entenderse incluida en todas las acciones judiciales que persiguen el cumplimiento de una obligación que el deudor ha intentado evadir mediante la instrumentalización abusiva de una sociedad. Como dice el profesor Ramón Domínguez Águila refiriéndose a la acción de inoponibilidad por fraude, "es muy posible incluso que esta acción quede encubierta o mejor dicho incorporada en la acción dirigida a obtener el cumplimiento o el reconocimiento del derecho vulnerado" 56 . Esto último lleva a la conclusión de que un tribunal puede prescindir de la personalidad jurídica de una sociedad sin necesidad de un juicio declarativo previo, e incluso si no se le ha solicitado expresamente el levantamiento del velo, si ello es necesario para lograr el debido reconocimiento de una pretensión legítima promovida en juicio: en realidad, la acción de inoponibilidad por fraude debe entenderse supuesta en toda pretensión que persiga lograr el respeto de un derecho que se ha intentado vulnerar injustamente. Lo anterior se desprende de la naturaleza decla-

53 NisSEN (2010) pp. 111 y 112.

54 Manóvil (1998) pp. 1049 y 1050.

55 Roitman, Aguirre y Chiavassa (2008) p. 271.

56 Domínguez Águila (1992) p. 94. 
rativa de la sentencia que acoge una acción o excepción de inoponibilidad por abuso de la personalidad jurídica, la que en definitiva se limita a reconocer una realidad preexistente. Por otra parte, la exigencia de un juicio declarativo previo implicaría de algún modo imponer dificultades adicionales al acreedor y facilitar la comisión del fraude, dando tiempo al deudor para perpetrar maniobras abusivas que impidan o dificulten gravemente el ejercicio de los legítimos derechos del acreedor.

Así lo reconoció la Corte de Apelaciones de Santiago en los casos "Scharfstein S.A. con Browne Keeling y Cía. Ltda. y Emparanza Paiva, Margarita Juliana” y "Proinvest Promotora de Inversiones S.A. con Trends Ingeniería S.A. y Datun Chile S.A.”, al establecer que si bien el acreedor podía iniciar las acciones que estimara convenientes para obtener la declaración de simulación, el fraude pauliano o cualquier otra encaminada a salvaguardar sus intereses, ello no era impedimento para que "en esta litis, a propósito de un incidente de ampliación de embargo, pueda alegarse la mala fe del deudor, pidiendo la aplicación de la doctrina del levantamiento del velo corporativo". El tribunal desechó en ambos casos los argumentos del voto de minoría, conforme al cual el levantamiento del velo debia ser materia de un juicio diverso en que se debatieran la simulación, el fraude pauliano o cualquier otra acción que persiguiera la ineficacia de los actos impugnados.

\section{LA ACCIÓN DE INOPONIBILIDAD POR ABUSO DE LA PERSONALIDAD JURÍDiCA Y OTRAS ACCIONES AFINES O RELACIONADAS}

La acción de inoponibilidad por abuso de la personalidad jurídica societaria no debe confundirse con la acción de indemnización por los perjuicios a que tal abuso haya dado lugar, no obstante lo cual ambas pueden ejercerse conjuntamente, pues persiguen fines diversos. Efectivamente, la acción de inoponibilidad tiene por objeto que en un caso concreto se prescinda de uno o más atributos derivados de la personalidad jurídica de una sociedad de cuya estructura se ha abusado, en términos tales que los derechos u obligaciones que se ha tratado de eludir mediante la comisión de un acto fraudulento se atribuyan directamente a quienes han cometido o permitido tal abuso, independientemente de si quien ejerce la acción ha sufrido o no un perjuicio actual. Así ocurre, por ejemplo, cuando una compañía transfiere una parte substancial de su patrimonio a uno de sus socios con el fin de impedir que un acreedor social pueda hacer efectivo su crédito contra la compañía, o que un tribunal pueda decretar un embargo u otra medida precautoria sobre los bienes transferidos: en tal caso, la acción de inoponibilidad busca que se prescinda de la separación patrimonial entre la sociedad y el socio, y por consiguiente que la obligación de pagar formalmente contraída por la sociedad se atribuya directamente al socio que, al recibir los bienes sociales, cometió o posibilitó el fraude.

En cambio, la acción de indemnización de perjuicios tiene por objeto el resarcimiento de todos los daños efectivamente sufridos como consecuencia de un abuso de la personalidad jurídica. Así, en el ejemplo precedente, lo que persigue el acreedor social que ejerce esta acción no es que se determine que las obligaciones de la compañía deudora sean imputadas al socio a quien se transfirieron los bienes sociales, sino que se le indemnice de todos los perjuicios a que haya dado lugar el acto fraudulento, incluyendo por ejemplo los gastos de la acción deducida, intereses y demás que se acrediten conforme a los medios de 
prueba legales. Respecto de la responsabilidad perseguida mediante la acción antes aludida, cabe advertir que es de naturaleza extracontractual, pues su causa no es el incumplimiento ni el cumplimiento imperfecto o retardado de un contrato, sino una actuación fraudulenta que ha buscado impedir el ejercicio de los legítimos derechos de una de sus partes ${ }^{57}$.

La acción de inoponibilidad por abuso de la personalidad jurídica debe asimismo distinguirse de la acción pauliana. Desde luego, la acción pauliana tiene por objeto la revocación de actos o contratos fraudulentos que implican una enajenación o al menos la constitución de un derecho a favor de un tercero, mientras que la acción de inoponibilidad por abuso de la personalidad jurídica no necesariamente persigue tal fin. Así, por ejemplo, en el caso "Catrilef Hernández, Salomón y otros con Pesca Cisne S.A.", el abuso no consistió en una transferencia fraudulenta, sino en que la estructura societaria discurrida por la demandada y sus compañías relacionadas para la explotación de un negocio había sido utilizada de modo que una de las compañías actuara directamente en Chile bajo la apariencia exterior de ser un agente de negocios ajenos, por lo cual pretendía no asumir responsabilidad alguna por las operaciones propias del negocio; mientras que otra compañía del grupo asumía toda la responsabilidad pero actuaba únicamente desde el extranjero, lo que en la práctica imposibilitaba o dificultaba gravemente cualquier demanda en su contra ejercida desde Chile ${ }^{58}$.

Pero incluso cuando la acción de inoponibilidad por abuso de la personalidad jurídica persigue revocar un acto o contrato realizado fraudulentamente en perjuicio de terceros, ella debe distinguirse de la acción pauliana. En efecto, la acción pauliana pretende más bien revocar las transferencias a un tercero ajeno al deudor, mientras que la acción de inoponibilidad por abuso de la personalidad jurídica busca revocar las transferencias en que el adquirente no es un tercero verdaderamente ajeno al deudor, sino relacionado con este último mediante vínculos societarios tales que generan entre ellos una substancial unidad económica y jurídica de la cual se ha abusado. Precisamente por eso la jurisprudencia, para levantar el velo societario, pone especial empeño en demostrar la unidad entre el socio y la sociedad, o entre las distintas sociedades de un mismo grupo empresarial.

De la diferencia antes mencionada se deriva el hecho de que la acción pauliana tenga un plazo de prescripción de solo un año, término considerablemente más acotado que el del común de las acciones, pues si el objeto más propio de esta acción es la inoponibilidad de las transferencias a terceros verdaderamente ajenos al deudor, un plazo mayor de prescripción sería perjudicial para el principio de libre circulación de los bienes. Por el contrario, este problema no existe en el caso de la acción de inoponibilidad por abuso de la personalidad societaria, ya que su objeto es la inoponibilidad de las transferencias abusivas entre personas unidas por vínculos societarios tales que no existe entre ellas una perfecta alteridad. De este modo, su ejercicio no perjudica la libre circulación de los bienes, y no hay por consiguiente razón alguna para aplicar a esta acción un plazo de prescripción menor al

\footnotetext{
57 Para entender la distinción entre (i) la imputación de los efectos de una actuación fraudulenta a una persona distinta de la sociedad instrumentalizada y (ii) la obligación de resarcir los perjuicios provocados, particularmente útil es analizar la doctrina argentina en la materia; al respecto, véase por ejemplo Richard (2008).

58 Para una breve descripción de los hechos de este caso, véase la nota 24 anterior.
} 
ordinario. Sin perjuicio de lo anterior, no hay problema en perseguir el abuso de la personalidad jurídica mediante una acción pauliana dentro del plazo legal, pues el objeto de esta última es lo suficientemente amplio como para admitirlo.

Conviene asimismo distinguir la acción de inoponibilidad por abuso de la personalidad jurídica de la acción de simulación, teniendo en cuenta que aquella se basa normalmente en una actuación fraudulenta cuyos efectos se pretende combatir. La principal diferencia entre la simulación ilícita y el fraude es que el acto simulado existe solo en apariencia, y de hecho las partes nunca quisieron que produjera efectos, mientras que el acto fraudulento tiene una existencia real, y las partes sí pretendieron que este produjera sus efectos propios. De lo anterior es posible deducir que el objeto de la acción de simulación es que se declare que el acto aparente no existe verdaderamente y que por consiguiente solo se reconozcan efectos al acto que las partes pretendieron mantener oculto, mientras que el objeto de la acción por fraude es que un activo que ha sido efectivamente transferido por el deudor vuelva a su patrimonio ${ }^{59}$.

\section{CONCLUSIONES}

Luego de constatar que el fenómeno del abuso de la personalidad jurídica societaria ocurre en Chile igual que en otros países, diversos fallos dictados en los últimos años por los tribunales superiores de justicia de nuestro país, incluyendo a la Corte Suprema, han prescindido en ciertos casos excepcionales de la separación personal y patrimonial de ciertas sociedades cuya estructura se había instrumentalizado de manera fraudulenta, aplicando la técnica judicial del levantamiento del velo.

Ahora bien, para que pueda aplicarse efectivamente esta técnica judicial, se requiere necesariamente la existencia de dos supuestos copulativos: primero, la identidad personal o patrimonial de una sociedad con uno o más de sus socios, administradores o compañías relacionadas; y segundo, la utilización abusiva de la estructura de dicha sociedad para defraudar la ley o los derechos de terceros.

Por otra parte, es posible aplicar el levantamiento del velo en Chile acudiendo a diversas reglas de derecho común, incluyendo aquellas que castigan el fraude a la ley, el fraude a los derechos de terceros, el abuso del derecho, la conducta contraria a los actos propios, la simulación ilícita, la causa ilícita y los actos de mala fe, entre otras. Así queda de manifiesto en los fallos dictados por los tribunales chilenos a que se ha hecho alusión más arriba.

Teniendo presente lo anterior, el levantamiento del velo puede pedirse mediante el ejercicio de las acciones que correspondan según la naturaleza del fundamento invocado en cada oportunidad. Sin embargo, la manera que en general resulta más propia para considerar el abuso de la personalidad jurídica es calificándolo de fraude, usualmente perpetrado mediante un abuso del derecho, razón por la cual la acción más adecuada para combatirlo es una cuyo objeto sea la inoponibilidad de la conducta fraudulenta.

59 Al respecto, véase Domínguez Águila (1992) p. 86. Asimismo, es útil la comparación que realiza Claro Solar entre la acción de simulación y la acción pauliana, que es una acción por fraude (Claro Solar (1979) pp. 648-650). 
En consecuencia, debe reconocerse la existencia de una acción ordinaria de naturaleza declarativa en virtud de la cual toda persona puede solicitar que se prescinda en un caso concreto de la personalidad jurídica de una sociedad instrumentalizada para perjudicarlo, y que se declare judicialmente que le son inoponibles los actos perpetrados en su perjuicio mediante un abuso de la personalidad jurídica.

No obstante lo anterior, la solicitud de esta clase de inoponibilidad puede efectuarse también por vía de excepción, mediante su acumulación a una acción principal de distinta naturaleza, con motivo de un incidente, o en general con ocasión de cualquier procedimiento en que ello resulte necesario para obtener la debida protección de una persona a quien se ha buscado perjudicar injustamente.

Asimismo, tal como lo han reconocido algunos fallos dictados por los tribunales superiores de justicia chilenos, y dada la naturaleza generalmente fraudulenta del abuso de la personalidad jurídica, el levantamiento del velo puede aplicarse siempre que ello resulte necesario para dar la debida protección a una persona que se ha intentado perjudicar mediante un abuso de la personalidad jurídica, y sin necesidad de un juicio declarativo previo.

Por último, vale la pena insistir en el carácter excepcional de este remedio jurisprudencial, ya que un abuso del mismo podría perjudicar la protección que se debe a las sociedades, a su personalidad jurídica y a su patrimonio separado, los cuales son fundamentales tanto desde un punto de vista jurídico como económico.

\section{BIBLIOGRAFÍA}

Abeliuk Manasevich, René (2008): Las Obligaciones (Editorial Jurídica de Chile, Santiago).

Aguad Deik, Alejandra (2002): Los Limites de la Personalidad Jurídica. La Doctrina del Levantamiento del Velo, en Estudios sobre Reformas al Código Civil y Código de Comercio. Segunda Parte (Editorial Jurídica de Chile, Santiago).

Alcalde Rodríguez, Enrique (2005): El Fraude a la Ley, en II Curso de Actualización Jurídica. Teorías del Derecho Civil Moderno (Ediciones Universidad del Desarrollo, Santiago).

Alcalde Rodríguez, Enrique (2008): La Sociedad Anónima. Autonomía Privada, Interés Social y Conflictos de Interés (Editorial Jurídica de Chile, Santiago).

Alessandri, Arturo, Somarriva, Manuel y Vodanovich, Antonio (2004): Tratado de las Obligaciones. Volumen del Cumplimiento e Incumplimiento de las Obligaciones, de la Protección de los Derechos del Acreedor, de la Insolvencia y las Formas de Pago de los Deudores Insolventes (Editorial Jurídica de Chile, Santiago).

Bainbridge, Stephen (2002): Corporation Law and Economics (Foundation Press, New York).

Baltra, Alberto (1935): Ensayo de una Teoría General de los Actos Inoponibles (Memoria Prueba para optar al Grado de Licenciado de la Facultad de Ciencias Juridicas y Sociales de la Universidad de Chile).

Barros Bourie, Enrique (2006): Tratado de Responsabilidad Extracontractual (Editorial Jurídica de Chile, Santiago). 
Boldó Roda, Carmen (2006): Levantamiento del Velo y Persona Jurídica en el Derecho Privado Español (Editorial Aranzadi S.A., Cizur Menor, Navarra).

Claro Solar, Luis (1923): La Ley Núm. 3918 de 14 de marzo de 1923 sobre Sociedades de Responsabilidad Limitada (Revista de Derecho y Jurisprudencia, Tomo XX, marzo a julio de 1923).

Claro Solar, Luis (1979): Explicaciones de Derecho Civil Chileno y Comparado, Tomo XI, De las Obligaciones, II (Editorial Jurídica de Chile, Santiago).

Corral Talciani, Hernán (2010): Contratos y Daños por Incumplimiento (Abeledo Perrot, Santiago).

Cozian, Maurice, Viandier, Alain y Deboissy, Florence (2005): Droit des Sociétés (LexisNexis, Paris).

Davis, Paul (2008): Gower and Davis' Principles of Modern Company Law (Sweet \& Maxwell, London).

Dobson, Juan M. (1986): Lifting the Veil in Four Countries: The Law of Argentina, England, France and the United States (The International and Comparative Law Quarterly, Vol. $\left.35 \mathrm{~N}^{\circ} 4\right)$.

Domínguez Águila, Ramón (1992): Fraus Omnia Corrumpit. Notas sobre el Fraude en el Derecho Civil (Revista de Derecho y Jurisprudencia, Tomo LXXXIX N 3 ).

Hansmann, Henry, Kraakman, Reinier y Squire, Richard (2006): Law and the Rise of the Firm (Harvard Law Review, Vol. $119 \mathrm{~N}^{\circ}$ 5).

Klein, William, Coffee, John, y Partnoy, Frank (2010): Business Organization and Finance (Foundation Press, New York).

León Hurtado, Avelino (1990): La Causa (Editorial Jurídica de Chile, Santiago).

López Díaz, Patricia (2003): La Doctrina del Levantamiento del Velo y la Instrumentalización de la Personalidad Jurídica (LexisNexis, Santiago).

López Santa María, Jorge (2010): Los Contratos. Parte General (Abeledo Perrot, Santiago).

Lyon Puelma, Alberto (2003): Personas Jurídicas (Ediciones Universidad Católica de Chile, Santiago).

Manóvil, Rafael Mariano (1998): Grupos de Sociedades en el Derecho Comparado (AbeledoPerrot, Buenos Aires).

Mereminskaya, Elina (2003): Levantamiento del Velo Societario (Gaceta Jurídica, No 280, pp. 17 y ss.).

Merle, Philippe (2010): Sociétés Commerciales (Editions Dalloz, Paris).

Nissen, Ricardo Augusto (1998): Curso de Derecho Societario (AD-HOC, Buenos Aires).

Nissen, Ricardo (2010): Ley de Sociedades Comerciales, Tomo I (Editorial Astrea, Buenos Aires).

O'kelly, Charles y Thompson, Robert (2006): Corporations and Other Business Associations (Aspen Publishers, New York).

Peñailillo Arévalo, Daniel (1983): El Pacto de Separación de Bienes y el Perjuicio a los Acreedores (Revista de Derecho y Jurisprudencia, Tomo LXXX).

Puelma, Álvaro (2003): Sociedades (Editorial Jurídica de Chile, Santiago de Chile).

Puga Vial, Juan Esteban (2011): La Sociedad Anónima y Otras Sociedades por Acciones en el Derecho Chileno (Editorial Jurídica de Chile, Santiago). 
Richard, Efraín Hugo (2008): Inoponibilidad de la Personalidad Juridica: Imputabilidad y Responsabilidad (Revista de Derecho Privado y Comunitario, N²008-3).

Ripert, George y Roblot, René (sous la direction de Germain, Michel) (2009): Traité de Droit Commercial. Tome 1, Volume 2, Les Sociétés Commerciales (Librairie Générale de Droit et de Jurisprudence, Paris).

Roitman, Horacio, Aguirre, Hugo y Chiavassa, Eduardo (2008): Inoponibilidad de la Personalidad Jurídica (Revista de Derecho Privado y Comunitario, No 2008-3).

Serick, Rolf (1958): Apariencia y Realidad en las Sociedades Mercantiles. El Abuso de Derecho por medio de la Persona Jurídica (Ediciones Ariel, Barcelona).

Urbina Molfino, Ignacio (2011): Levantamiento del Velo Corporativo. Sentencia de la Corte Suprema de 2 de junio de 2009 (Revista Chilena de Derecho, Vol. $38 \mathrm{~N}^{\circ}$ 1).

Vargas Vargas, Manuel (1949): Tratado de la Acción Pauliana Concursal (Ediar Editores Limitada, Santiago). 